\title{
Pearl Millet (Pennisetum glaucum L.) As Affected by Some Agricultural Treatments
}

Fayed, M. H.; M. Sh. A. Salem and O. M. A. M. Abd EL-Kader

Dep. of Agron ., Fac. of Agric., AL-Azhar Univ.

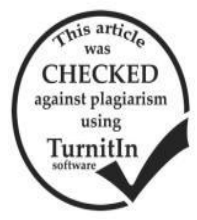

\begin{abstract}
Two field experiments, were conducted at Agricultural Research Farm, Agronomy Department, Faculty of Agriculture, AL-Azhar Univ. Madenit Nasser during 2013 and 2015 summer seasons to study the influence of irrigation regimes ( 40\%,60\% and $80 \%$ depletion of field capacity), sowing dates $\left(20^{\text {th }}\right.$ of April , $20^{\text {th }}$ of May and $20^{\text {th }}$ of June $)$ as well as nitrogen fertilizer rates $(80,100$ and $120 \mathrm{~kg} \mathrm{~N} / \mathrm{fad}$.) on the yield and yield components of pearl millet, (Shandaweil 1 var.). The results revealed that, irrigation at $40 \%$ depletion of field capacity awarded the highest significant means for plant height, fresh and dry weight/plant and fresh and dry forage yield / fad. in both growing seasons. In both growing seasons, the first sowing date $\left(20^{\text {th }}\right.$ April ) was the most significant one due to the previous parameters. The highest means of the above mentioned characters were obtained by $120 \mathrm{~kg} \mathrm{~N} / \mathrm{fad}$.. As for interactions. irrigation at $40 \%$ depletion of field capacity during the first sowing date $\left(20^{\text {th }}\right.$ April ) awarded the heaviest plants, while the two sowing dates $\left(20^{\text {th }}\right.$ April and $20^{\text {th }}$ May ) Also, the application of $120 \mathrm{~kg}$ N/fad. gave the best results for the most characters under study.
\end{abstract}

\section{INTRODUCTION}

Nowadays, animal production in Egypt is suffering from scarcity due to the competition between the production of human food and animal feed. In Egypt, there is shortage of fresh food materials of livestock feeding during summer season, from May until November.Pearl millet (Pennisetum glaucum, L.) is a high nutritive value summer-annual forage crop, popular among livestock producers for grazing, silage, hay and green crop. Pearl millet can also be utilized as emergency forage that regularly performs as well as an economical one-year forage crop option. It is an important forage crop of Africa, Asia and America (Dakheel et al., 2009 and Newman et al., 2010). Pearl millet is extensively used in different countries as forage of high nutritional quality (Maiti and Rodriguez, 2010). It is rich in protein and energy and poor in fiber and lignin concentration. Crude protein can range from 9 to $11 \%$ in unfertilized soils and to 14 to $15 \%$ under nitrogen-fertilized conditions. It is also rich in calcium, iron and has balanced amino acids, but its sulfur-containing amino acid concentration is low. Pearl millet is considered the main forage crop for feeding animals during summer season in Egypt . Irrigation is the most effective major factor limiting the increasing productivity of forage crops area, also, it affects the fresh and dry forage yield as well as the quality of production i.e., crude protein yield under newly reclaimed soil conditions. So, it is important to determine the water requirements for high production and high quality of crops, also they should be depend on the irrigation technologies to save large amount of water and enhance the water use efficiency which increase the crop yield, also helps in maintaining the ecological balance . Abdel-Gawad (1993), demonstrated that forage crops, in general, irrigated after the depletion of 30 or $50 \%$ of the available soil moisture produced the greatest fresh and dry yields. On the same line. Ibrahim (1985), confirmed that fodder and dry matter yields of pearl millet were reduced under drought stress condition.

Deshmukh et al. (2013), investigated that through his experiment on pear millet to show the effect of different land configuration and dates of sowing on ensuming economic gains. The gained results confirmed that rides and furrow along with early sowing date during summer season is beneficial to obtain higher net returns from pear millet crop. With respect to the effect of sowing date on pearl millet, weather condition plays an important role on growth and yield of pear millet in summer season. The meteorological data indicated that weather conditions prevailed during the entire crop period was favorable and congenial for the normal growth and development of pear millet crop. Pear millet plant height, leaf area and dry matter accumulation measured at 20 DAS was not significant due to changes in sowing time. Whereas sown at normal time registered measurable increase in growth components as compared to late sown crop. Yassin et al.(2014), concluded that a positive significant effects on fresh weight, dry weight, number of leaves/plant and forage yield which indicate the ability to grow millet successfully during April as a forage crop. The results recorded that additional of 120 $\mathrm{kg} \mathrm{N} / \mathrm{fad}$ obtained significant effects in both seasons. The results showed that cultivar has a wide response to nitrogen fertilizer under irrigation conditions in both seasons of millet. The objective of this investigation is to study the influence of irrigation regimes, sowing dates and nitrogen fertilization rates on yield and its components of pearl millet.

\section{MATERIALS AND METHODS}

During 2013 and 2015 Summer seasons, two field experiments were conducted in Agric. Res. Farm, Agron. Dep . Fac . Agric. Al -Azhar Univ. Madenit Nasser , Cairo , Egypt to study the effect of irrigation regimes, sowing dates and nitrogen fertilizer rates on yield and yield components as well as water use efficiency of pearl millet (Pennisetum glaucum) Shandaweil 1 var. that was obtained from Forage Crops Res. Section, Agric . Res . Center, Egypt.

\section{Studied factors:}

a-Irrigation regimes ( IR) :

1. Irrigation up to $40 \%$ depletion of field capacity $\left(\mathrm{IR}_{1}\right)$.

2. Irrigation up to $60 \%$ depletion of field capacity $\left(\mathrm{IR}_{2}\right)$.

3. Irrigation up to $80 \%$ depletion of field capacity $\left(\mathrm{IR}_{3}\right)$. 
b- Sowing dates (SD):

1. The $20^{\text {th }}$ of April .

2. The $20^{\text {th }}$ of May .

3. The $20^{\text {th }}$ of June .

c- Nitrogen fertilizer rates $(\mathbf{N})$ :

1. Adding $80 \mathrm{~kg} \mathrm{~N} / \mathrm{fad}$.

2. Adding $100 \mathrm{~kg} \mathrm{~N} /$ fad.

3. Adding $120 \mathrm{~kg} \mathrm{~N} /$ fad.

A split split plot design with three repplications was practiced. The main plots were devoted to irrigation regimes, the sub plots were assigned to sowing dates, whereas the sub- sub plots were experimented to nitrogen fertilizer rates.

With regard to irrigation treatments, Table 1 shows the additive water for each field capacity level through the first and second season .

Dry method of sowing (Hafier method ) was used where the seeds were sown in lines, the distance between lines $20 \mathrm{~cm}$ and the experimental plot area was $6 \mathrm{~m}^{2}(2 \times 3 \mathrm{~m})$. The preceding winter crop was barley in the first season and wheat in the second one.

Table(1):- The additive water $\mathrm{m}^{3}$ /fad. for each field capacity level through the three sowing dates during 2013 and 2015 seasons.

\begin{tabular}{|c|c|c|c|c|c|c|}
\hline \multirow[t]{2}{*}{ Irrigation regime (IR) } & \multicolumn{3}{|c|}{$\begin{array}{c}2013 \text { season } \\
\text { Sowing date }(\mathrm{SD})\end{array}$} & \multicolumn{3}{|c|}{$\begin{array}{c}2015 \text { season } \\
\text { Sowing date }(\mathrm{SD})\end{array}$} \\
\hline & $20^{\text {th }}$ April & $20^{\text {th }}$ May & $20^{\text {th }}$ June & $20^{\text {th }}$ April & $20^{\text {th }} \quad$ May & $20^{\text {th }}$ June \\
\hline $40 \%\left(\mathrm{IR}_{1}\right)$ deplet. $\mathrm{m}^{3} / \mathrm{fad}$ & 2700 & 2250 & 1800 & 2820 & 2400 & 1900 \\
\hline $60 \%\left(\mathrm{IR}_{2}\right)$ deplet.m ${ }^{3} / \mathrm{fad}$ & 2340 & 1800 & 1440 & 2250 & 1800 & 1435 \\
\hline $80 \%\left(\mathrm{IR}_{3}\right)$ deplet.m ${ }^{3} / \mathrm{fad}$ & 1710 & 1350 & 1080 & 1875 & 1440 & 1150 \\
\hline
\end{tabular}

Before sowing, Calcium super phosphate $(15.5 \%$ $\left.\mathrm{P}_{2} \mathrm{O}_{5}\right)$ and Potassium sulphate $\left(48 \% \mathrm{~K}_{2} \mathrm{O}\right)$ were added at the rate of 150 and $50 \mathrm{~kg} / \mathrm{fad}$. , respectively. Nitrogen fertilizer was added as ammonium nitrate $(33.5 \% \mathrm{~N})$ relying on the studied doses, the first dose was added after 15 days from sowing, the second one was applied after the first cut and the third one was practiced after the second cut. All normal culture treatments as well as plant protection were practiced as usually done for pearl millet crop. The soil texture was sand clay the and chemical and mechanical analysis according to the experimental soil for the first and second seasons were tabulated in Table (2).

Table (2) :- Illustrated the chemical and mechanical properties of the experimental soil during the two growing seasons.

\begin{tabular}{lcccccccc}
\hline Season & $\mathbf{p H}$ & $\begin{array}{c}\mathbf{N} \\
\mathbf{m g} / \mathbf{k g} \text {. soil }\end{array}$ & $\begin{array}{c}\mathbf{P} \\
\mathbf{m g} / \mathbf{k g} \text {. soil }\end{array}$ & $\begin{array}{c}\mathbf{K} \\
\mathbf{m g} / \mathbf{k g} \text {. soil }\end{array}$ & $\begin{array}{c}\mathbf{E c} \\
\mathbf{m} \text {. } \mathbf{m o h s} / \mathbf{c m}\end{array}$ & $\begin{array}{c}\text { Sand } \\
\mathbf{\%}\end{array}$ & $\begin{array}{c}\text { Silt } \\
\boldsymbol{\%}\end{array}$ & $\begin{array}{c}\text { Clay } \\
\mathbf{\%}\end{array}$ \\
\hline 2013 & 7.5 & 1.2 & 0.23 & 0.296 & 1.73 & 55.6 & 7.4 & 37.0 \\
2015 & 7.2 & 1.2 & 0.18 & 0.256 & 1.63 & 53.7 & 9.2 & 37.1 \\
\hline
\end{tabular}

In each season three cuts were taken after 60,95 and 130 days from the first sowing date, whereas two cuts only at the same previous date were achieved from the second sowing date, only one cut at 60 days was carried out from the third sowing date under study at a cutting height of approximately $10 \mathrm{~cm}$ for studying the following pearl millet characters.

The studied characters:-

\section{A-Yield and yield components:-}

1-Plant height $(\mathrm{cm}) \quad 2$-Fresh weight/plant $(\mathrm{g})$

3-Dry weight/plant(g ) 4 -Fresh forage yield /fad.(ton)

5- Dry forage yield / fad.(ton)

\section{B-Water relations:-}

Water use efficiency:- It was calculated according to this formula (Eck , 1988)

W.U.E. = dry matter $\mathrm{kg}$. /used irrigation water $\mathrm{m}^{3}$

Statistical analysis:-

The analysis of variance was used according to Snedecor and Cochran (1981), the least significant difference (L.S.D) test at 5\% level of significance was used to indicate treatment differences.

\section{RESULTS AND DISCUSSION}

Yield and yield components:-

Results in Table (3) reveal significant effect for irrigation regimes on plant height through 2013 and 2015 seasons. It was noticed that, irrigation at $40 \%$ depletion of field capacity achieved significant increase plant height, in both successive seasons as compared with irrigation at $80 \%$ depletion of field capacity. For example, irrigation pearl millet at $80 \%$ depletion of field capacity decreased plant height by $16.19 \%$ in the first season and by $18.55 \%$ in the second one, as enduring with irrigation up to $40 \%$ depletion of field capacity. The previous observations may be due to day time growth of plants is often reduced by water deficits caused by excessive midday transpiration and plants growing in moist soil or aerated nutrient solutions sometimes wilt on hot, sunny days. In general, midday water stress is more severe in dry climates, but it occurs in the humid tropics, as explicated by Tazaki et al., (1980). These results are in the same direction with those reported by Okpara and Omaliko(1995). Respecting to, the significant impact of sowing date on plant height, in both growing seasons, the $20^{\text {th }}$ April 
sowing date awarded the highest plants $(80.70$ and $82.40 \mathrm{~cm}$ ), they significantly differed comparing with the $20^{\text {th }}$ June that gave the shortest plants $(73.18$ and $52.20 \mathrm{~cm}$ ). These above findings may be owing to a later sowing date of forage crops reduced time of vegetative development that reflected on plant height, as demonstrated by Kwapata and Hall (1990), these findings are advocated by Deshmukh et al. (2013). It is interesting to note that, plant height was increased gradually with significant level as enhancing nitrogen fertilizer rates from 80 up to $120 \mathrm{~kg} \mathrm{~N} /$ fad. plant height was enhanced by $23.36 \%$ in the first season and by $18.72 \%$ in the second one. These above results may be due to the chemical or mineral fertilizers i.e. nitrogen fertilizers are richer in their nutrient contents, less bulky, easier to transport and apply in the field, thus show quick response on crop growth, as reported by Hussain et al.(1987). As for the significant impact of the two interactions $(\mathrm{IR} \times \mathrm{SD})$ and $(\mathrm{SD} \times \mathrm{N})$ on pearl millet plant height, during 2013 and 2015 experimental seasons. Results cleared that irrigation the plants at 40 $\%$ depletion of field capacity $\left(\mathrm{IR}_{1}\right)$ during the first SD (the $20^{\text {th }}$ April ) awarded the tallest plants 91.77 and $91.27 \mathrm{~cm}$, while under the same circumstances of irrigation regime $\left(\mathrm{IR}_{1}\right)$ during the second $\mathrm{SD}$ (the $20^{\text {th }}$ May ) gave the second order 86.44 and $84.61 \mathrm{~cm}$, whereas the shortest plants 67.44 and $46.50 \mathrm{~cm}$ were gained as exposing the plants to irrigate at $80 \%$ depletion of field capacity $\left(\mathrm{IR}_{3}\right)$ during the third $\mathrm{SD}$ (the $20^{\text {th }}$ June ) in the first and second experimental seasons . On the other hand, the two sowing dates (the $20^{\text {th }}$ April and the $20^{\text {th }}$ May ) with the application of 120 $\mathrm{kg} \mathrm{N} / \mathrm{fad}$. gave the tallest plants, where as the shortest plants were obtained from sowing the plants at the $20^{\text {th }}$ June with the addition of $80 \mathrm{~kg} \mathrm{~N} / \mathrm{fad}$..

Table:(3) Effect of irrigation regimes, sowing dates and nitrogen fertilizer rates on plant height of pearl millet $(\mathrm{cm})$ in 2013 and 2015 seasons

\begin{tabular}{|c|c|c|c|c|c|c|c|c|c|}
\hline \multirow[t]{2}{*}{$\begin{array}{l}\text { Irrigation } \\
\text { regime } \\
\text { (IR) }\end{array}$} & \multirow[t]{2}{*}{$\begin{array}{c}\text { Sowing } \\
\text { date(SD) }\end{array}$} & \multicolumn{3}{|c|}{$\begin{array}{l}2013 \text { season } \\
\text { Nitrogen fertilizer rate } \\
\text { (N) } \mathrm{kg} / \text { fad. }\end{array}$} & \multirow[t]{2}{*}{ Mean } & \multicolumn{3}{|c|}{$\begin{array}{l}2015 \text { season } \\
\text { ogen fertilizer rate } \\
\text { (N) } \mathrm{kg} / \mathrm{fad} .\end{array}$} & \multirow[t]{2}{*}{ Mean } \\
\hline & & 80 & 100 & 120 & & 80 & 100 & 120 & \\
\hline \multirow{4}{*}{$\begin{array}{l}40 \% \\
\left(\mathrm{IR}_{1}\right)\end{array}$} & $20^{\text {th }}$ April & 81.33 & 94.66 & 99.33 & 91.77 & 83.66 & 90.50 & 99.66 & 91.27 \\
\hline & $20^{\text {th }}$ May & 77.66 & 88.33 & 93.33 & 86.44 & 78.00 & 83.50 & 92.33 & 84.61 \\
\hline & $20^{\text {th }}$ June & 73.16 & 79.66 & 83.16 & 78.66 & 54.16 & 58.16 & 63.33 & 58.55 \\
\hline & Mean & 77.38 & 87.55 & 91.94 & 85.62 & 71.94 & 77.38 & 85.11 & 78.14 \\
\hline \multirow{3}{*}{$\begin{array}{l}60 \% \\
\left(\mathrm{IR}_{2}\right)\end{array}$} & $20^{\text {th }}$ April & 67.66 & 79.00 & 87.00 & 77.88 & 77.00 & 81.83 & 86.83 & 81.88 \\
\hline & $20^{\text {th }}$ May & 73.00 & 84.16 & 87.33 & 81.50 & 70.33 & 76.50 & 84.33 & 77.05 \\
\hline & $20^{\text {th }}$ June & 64.83 & 74.00 & 81.50 & 73.44 & 48.16 & 51.66 & 54.83 & 51.55 \\
\hline \multirow{5}{*}{$\begin{array}{l}80 \% \\
\left(\mathrm{IR}_{3}\right)\end{array}$} & Mean & 68.50 & 79.05 & 85.27 & 77.61 & 65.16 & 70.00 & 75.33 & 70.16 \\
\hline & $20^{\text {th }}$ April & 59.66 & 75.00 & 82.66 & 72.44 & 66.50 & 74.33 & 81.33 & 74.05 \\
\hline & $20^{\text {th }}$ May & 65.66 & 79.00 & 81.50 & 75.38 & 63.00 & 71.16 & 77.00 & 70.38 \\
\hline & $20^{\text {th }}$ June & 60.66 & 68.16 & 73.50 & 67.44 & 42.00 & 45.33 & 52.16 & 46.50 \\
\hline & Mean & 62.00 & 74.05 & 79.22 & 71.75 & 57.16 & 63.61 & 70.16 & 63.64 \\
\hline \multirow{3}{*}{$\begin{array}{l}\text { Mean of } \\
\text { Sowing } \\
\text { dates(SD) }\end{array}$} & $20^{\text {th }}$ April & 69.55 & 82.88 & 89.66 & 80.70 & 75.72 & 82.22 & 89.27 & 82.40 \\
\hline & $20^{\text {th }}$ May & 72.11 & 83.83 & 87.38 & 81.11 & 70.44 & 77.05 & 84.55 & 77.35 \\
\hline & $20^{\text {th }}$ June & 66.22 & 73.94 & 79.38 & 73.18 & 48.11 & 51.72 & 56.77 & 52.20 \\
\hline \multicolumn{2}{|c|}{$\begin{array}{l}\text { Mean of } \\
\text { Nitrogen rates }(\mathrm{N})\end{array}$} & 69.29 & 80.22 & 85.48 & & 64.75 & 70.33 & 76.87 & \\
\hline \multicolumn{10}{|c|}{ LSD at $0.05 \%$ level for } \\
\hline \multicolumn{2}{|c|}{ Irrigation regimes (IR) } & \multicolumn{4}{|c|}{1.43} & \multicolumn{4}{|c|}{2.69} \\
\hline \multicolumn{2}{|c|}{ Sowing dates(SD) } & \multicolumn{4}{|c|}{2.27} & \multicolumn{4}{|c|}{1.51} \\
\hline \multicolumn{2}{|c|}{ Nitrogen rates $(\mathrm{N})$} & \multicolumn{4}{|c|}{1.74} & \multicolumn{4}{|c|}{0.97} \\
\hline \multicolumn{2}{|c|}{ IRxSD } & \multicolumn{4}{|c|}{3.94} & \multicolumn{4}{|c|}{2.62} \\
\hline \multicolumn{2}{|l|}{ IRxN } & \multicolumn{4}{|c|}{ N.S } & \multicolumn{4}{|c|}{ N.S } \\
\hline \multicolumn{2}{|l|}{ SDxN } & \multicolumn{4}{|c|}{3.01} & \multicolumn{4}{|c|}{1.67} \\
\hline \multicolumn{2}{|l|}{ IRx SDx N } & & & & & & & & \\
\hline
\end{tabular}

From Tables 4 and 5 , plant fresh and dry weight were significantly declined and depressed by 14.60 , $30.37,14.17$ and $33.06 \%$ respectively, as enhancing the drought stress (from $40 \%, 60 \%$ up to $80 \%$ depletion of field capacity ), in the first growing season. Similar observations had been detected in the second one.
These findings are owing to, reduction in leaf area by water stress is an important cause of reduced crop component i.e. fresh and dry weight / plant and fad. because the reduced photosynthetic surface after the stress is relieved(Kramer, 1983). These results are in harmony with those gained by Abdel - Gawad (1993). 
The highest significant fresh and dry weight/plant (40.78 and $15.95 \mathrm{~g}$ ) associated with the first sowing date, in the first growing season, while $32.90 \mathrm{~g}$ and $12.54 \mathrm{~g}$ attributed with the second sowing date , as shown in the second growing season. In general the lowest fresh and dry weight $(29.44 \mathrm{~g}, 22.65 \mathrm{~g}, 11.75 \mathrm{~g}$ and $11.59 \mathrm{~g} / \mathrm{plant}$ ) were obtained from sowing date at the $20^{\text {th }}$ June , in 2013 and 2015 seasons, respectively .These results are quite in line with those reported by Aftab et al. (2004) found that in May field crops there is a significant relationship between dry matter production and intercepted photosynthetically active radiation, it was liner throughout the growing season. It was obvious that, fresh and dry weight/plant were significantly enhanced with increasing nitrogen rate from 80 up to $120 \mathrm{~kg} / \mathrm{fad}$. the application of $120 \mathrm{~kg} \mathrm{~N} / \mathrm{fad}$. increased fresh and dry weight/plant (40.81 and $34.76,16.19$ and $14.43 \mathrm{~g}$ ) in the first and second seasons comparing with the lowest nitrogen fertilizer rate(80 $\mathrm{kg} \mathrm{N}$ /fad.).Enhancing fresh and dry weight/plant with increasing nitrogen fertilizer in separated doses may be due to the nitrification pattern of ammoniacal material provides little justification for the belief that these forms in warm, well- aerated and moist soils release their nitrogen slowly, thus reducing excessive looses by leaching, as explained by Tisdal and Nelson (1966). These results are in accordance with those reported by Tariq et al. (2009). Generally , most of the studied interactions results differed within the two studied traits and growing seasons. For example, sowing the seeds on the $20^{\text {th }}$ April with the application of $120 \mathrm{~kg} \mathrm{~N} / \mathrm{fad}$. gave the maximum fresh weight/plant $(49.43 \mathrm{~g})$, it was followed by $(39.22 \mathrm{~g})$ that was obtained from sowing at the same previous date with the addition of $100 \mathrm{~kg} \mathrm{~N}$ /fad. , in the first growing season. But in the second one , planting the seeds on the $20^{\text {th }}$ May and fertilized with $120 \mathrm{~kg} \mathrm{~N} / \mathrm{fad}$. resulted in the greatest fresh weight /plant $(40.44 \mathrm{~g})$, the second order (36.94 g) was gained from sowing the seeds on the $20^{\text {th }}$ April under the same condition of the previous fertilizer rate . In both seasons, the minimum fresh weight / plant $(22.94$ and $17.74 \mathrm{~g})$ associated with sowing the seeds on the $20^{\text {th }}$ June with the application of $80 \mathrm{~kg} \mathrm{~N} / \mathrm{fad}$.

Table:(4) Effect of irrigation regimes, sowing dates and nitrogen fertilizer rates on the fresh weight/plant of pearl millet (g) in 2013 and 2015 seasons

\begin{tabular}{|c|c|c|c|c|c|c|c|c|c|}
\hline \multirow[t]{2}{*}{$\begin{array}{l}\text { Irrigation } \\
\text { regime } \\
\text { (IR) }\end{array}$} & \multirow[t]{2}{*}{$\begin{array}{c}\text { Sowing } \\
\text { date(SD) }\end{array}$} & \multicolumn{3}{|c|}{$\begin{array}{l}2013 \text { season } \\
\text { Nitrogen fertilizer rate } \\
\text { (N) } \mathrm{kg} / \text { fad. }\end{array}$} & \multirow[t]{2}{*}{ Mean } & \multicolumn{3}{|c|}{$\begin{array}{l}2015 \text { season } \\
\text { ogen fertilizer rate } \\
\text { (N) } \mathrm{kg} / \mathrm{fad} \text {. }\end{array}$} & \multirow[t]{2}{*}{ Mean } \\
\hline & & 80 & 100 & 120 & & 80 & 100 & 120 & \\
\hline \multirow{4}{*}{$\begin{array}{l}40 \% \\
\left(\mathrm{IR}_{1}\right)\end{array}$} & $20^{\text {th }}$ April & 38.33 & 45.93 & 57.03 & 47.10 & 28.00 & 35.83 & 41.33 & 35.05 \\
\hline & $20^{\text {th }}$ May & 29.46 & 37.23 & 45.43 & 37.37 & 29.33 & 39.80 & 44.26 & 37.80 \\
\hline & $20^{\text {th }}$ June & 27.33 & 36.26 & 43.26 & 35.62 & 21.26 & 26.53 & 33.90 & 27.23 \\
\hline & Mean & 31.71 & 39.81 & 48.57 & 40.03 & 26.20 & 34.05 & 39.83 & 33.36 \\
\hline \multirow{4}{*}{$\begin{array}{l}60 \% \\
\left(\mathrm{IR}_{2}\right)\end{array}$} & $20^{\text {th }}$ April & 36.56 & 40.26 & 49.03 & 41.95 & 21.83 & 29.66 & 37.00 & 29.50 \\
\hline & $20^{\text {th }}$ May & 25.53 & 31.20 & 38.00 & 31.57 & 23.50 & 33.16 & 40.80 & 32.48 \\
\hline & $20^{\text {th }}$ June & 23.80 & 29.73 & 33.63 & 29.05 & 18.16 & 23.56 & 25.50 & 22.41 \\
\hline & Mean & 28.63 & 33.73 & 40.22 & 34.19 & 21.16 & 28.80 & 34.43 & 28.13 \\
\hline \multirow{4}{*}{$\begin{array}{l}80 \% \\
\left(\mathrm{IR}_{3}\right)\end{array}$} & $20^{\text {th }}$ April & 26.16 & 31.46 & 42.23 & 33.28 & 17.33 & 23.83 & 32.50 & 24.55 \\
\hline & $20^{\text {th }}$ May & 22.33 & 27.40 & 30.30 & 26.67 & 22.06 & 26.96 & 36.26 & 28.43 \\
\hline & $20^{\text {th }}$ June & 17.70 & 24.83 & 28.43 & 23.65 & 13.80 & 19.83 & 21.30 & 18.31 \\
\hline & Mean & 22.06 & 27.90 & 33.65 & 27.87 & 17.73 & 23.54 & 30.02 & 23.76 \\
\hline \multirow{3}{*}{$\begin{array}{l}\text { Mean of } \\
\text { Sowing } \\
\text { dates(SD) }\end{array}$} & $20^{\text {th }}$ April & 33.68 & 39.22 & 49.43 & 40.78 & 22.38 & 29.77 & 36.94 & 29.70 \\
\hline & $20^{\text {th }}$ May & 25.77 & 31.94 & 37.91 & 31.87 & 24.96 & 33.31 & 40.44 & 32.90 \\
\hline & $20^{\text {th }}$ June & 22.94 & 30.27 & 35.11 & 29.44 & 17.74 & 23.31 & 26.90 & 22.65 \\
\hline \multicolumn{2}{|c|}{$\begin{array}{l}\text { Mean of } \\
\text { Nitrogen rates }(\mathrm{N})\end{array}$} & 27.47 & 33.81 & 40.81 & & 21.70 & 28.80 & 34.76 & \\
\hline \multicolumn{10}{|c|}{ LSD at $0.05 \%$ level for } \\
\hline \multicolumn{2}{|c|}{ Sowing dates(SD) } & \multicolumn{4}{|c|}{1.50} & \multicolumn{4}{|c|}{1.07} \\
\hline \multicolumn{2}{|c|}{ Nitrogen rates $(\mathrm{N})$} & \multicolumn{4}{|c|}{1.25} & \multicolumn{4}{|c|}{1.44} \\
\hline \multicolumn{2}{|l|}{ IRxSD } & \multicolumn{4}{|c|}{ N.S } & \multicolumn{4}{|c|}{ N.S } \\
\hline \multicolumn{2}{|l|}{ IRxN } & \multicolumn{4}{|c|}{ N.S } & \multicolumn{4}{|c|}{ N.S } \\
\hline \multicolumn{2}{|l|}{ SDxN } & \multicolumn{4}{|c|}{2.18} & \multicolumn{4}{|c|}{2.49} \\
\hline \multicolumn{2}{|l|}{ IRx SDx N } & \multicolumn{3}{|c|}{ N.S } & & & & & \\
\hline
\end{tabular}


Table:(5) Effect of irrigation regimes, sowing dates and nitrogen fertilizer rates on dry weight/plant of pearl millet (g) in 2013 and 2015 seasons

\begin{tabular}{|c|c|c|c|c|c|c|c|c|c|}
\hline \multirow{2}{*}{$\begin{array}{l}\text { Irrigation } \\
\text { regime } \\
\text { (IR) }\end{array}$} & \multirow[t]{2}{*}{$\begin{array}{c}\text { Sowing } \\
\text { date(SD) }\end{array}$} & \multicolumn{3}{|c|}{$\begin{array}{l}2013 \text { season } \\
\text { Nitrogen fertilizer rates } \\
\text { (N) } \mathrm{kg} / \text { fad. }\end{array}$} & Mean & \multicolumn{3}{|c|}{$\begin{array}{l}2015 \text { season } \\
\text { Nitrogen fertilizer rates } \\
\text { (N) } \mathrm{kg} / \text { fad. }\end{array}$} & \multirow[t]{2}{*}{ Mean } \\
\hline & & 80 & 100 & 120 & & 80 & 100 & 120 & \\
\hline $40 \%$ & $20^{\text {th }}$ April & 15.33 & 18.36 & 22.93 & 18.87 & 12.60 & 16.13 & 18.56 & 15.76 \\
\hline \multirow{4}{*}{$\left(\mathrm{IR}_{1}\right)$} & $20^{\text {th }}$ May & 12.10 & 15.20 & 19.23 & 15.51 & 11.60 & 12.80 & 16.86 & 13.75 \\
\hline & $20^{\text {th }}$ June & 11.26 & 14.96 & 17.36 & 14.53 & 10.50 & 13.16 & 16.60 & 13.42 \\
\hline & Mean & 12.9 & 16.17 & 19.84 & 16.30 & 11.56 & 14.03 & 17.34 & 14.31 \\
\hline & $20^{\text {th }}$ April & 14.63 & 16.10 & 19.60 & 16.77 & 9.83 & 13.46 & 16.66 & 13.32 \\
\hline $60 \%$ & $20^{\mathrm{th}}$ May & 11.03 & 13.50 & 16.20 & 13.57 & 10.86 & 12.93 & 14.50 & 12.76 \\
\hline \multirow[t]{3}{*}{$\left(\mathrm{IR}_{2}\right)$} & $20^{\text {th }}$ June & 9.53 & 11.93 & 13.43 & 11.63 & 9.00 & 11.73 & 12.63 & 11.12 \\
\hline & Mean & 11.73 & 13.84 & 16.41 & 13.99 & 9.90 & 12.71 & 14.60 & 12.40 \\
\hline & $20^{\text {th }}$ April & 10.46 & 12.60 & 13.56 & 12.21 & 7.80 & 10.73 & 14.60 & 11.04 \\
\hline $80 \%$ & $20^{\text {th }}$ May & 9.60 & 11.96 & 12.80 & 11.45 & 11.03 & 11.23 & 11.10 & 11.12 \\
\hline \multirow[t]{2}{*}{$\left(\mathrm{IR}_{3}\right)$} & $20^{\text {th }}$ June & 7.10 & 9.53 & 10.63 & 9.08 & 6.83 & 9.83 & 14.06 & 10.24 \\
\hline & Mean & 9.05 & 11.36 & 12.33 & 10.91 & 8.55 & 10.60 & 10.01 & 9.72 \\
\hline Mean of & $20^{\text {th }}$ April & 13.47 & 15.68 & 18.70 & 15.95 & 10.07 & 13.44 & 16.61 & 13.37 \\
\hline Sowing & $20^{\text {th }}$ May & 10.91 & 13.55 & 16.07 & 13.51 & 11.16 & 12.32 & 14.15 & 12.54 \\
\hline dates(SD) & $20^{\text {th }}$ June & 9.30 & 12.14 & 13.81 & 11.75 & 8.77 & 11.57 & 14.43 & 11.59 \\
\hline \multicolumn{2}{|c|}{$\begin{array}{l}\text { Mean of } \\
\text { Nitrogen rates }(\mathrm{N})\end{array}$} & 11.22 & 13.79 & 16.19 & & 10.00 & 12.44 & 13.98 & \\
\hline \multicolumn{10}{|c|}{ LSD at $0.05 \%$ level for } \\
\hline \multicolumn{2}{|c|}{ Irrigation regimes (IR) } & \multicolumn{4}{|c|}{0.78} & \multicolumn{4}{|c|}{0.43} \\
\hline \multicolumn{2}{|c|}{ Sowing dates(SD) } & \multicolumn{4}{|c|}{0.51} & \multicolumn{4}{|c|}{0.90} \\
\hline \multicolumn{2}{|c|}{ Nitrogen rates $(\mathrm{N})$} & \multicolumn{4}{|c|}{0.52} & \multicolumn{4}{|c|}{0.76} \\
\hline \multicolumn{2}{|c|}{ IRxSD } & \multicolumn{4}{|c|}{0.89} & \multicolumn{4}{|c|}{1.57} \\
\hline \multicolumn{2}{|l|}{ IRxN } & \multicolumn{4}{|c|}{0.90} & \multicolumn{4}{|c|}{0.85} \\
\hline \multicolumn{2}{|l|}{ SDxN } & \multicolumn{4}{|c|}{ N.S } & \multicolumn{4}{|c|}{1.30} \\
\hline \multicolumn{2}{|l|}{ IRx SDx N } & \multicolumn{3}{|c|}{ N.S } & & \multicolumn{3}{|c|}{ N.S } & \\
\hline
\end{tabular}

From Tables 6 and 7 , exposing pearl millet plants to irrigate stress till $80 \%$ depletion of field capacity reduced fresh and dry forage yield by $25.68 \%$ and 23.38 $\%$ in the first successive season, while it was $27.09 \%$ and $23.99 \%$ in the second one, respectively, as compared with irrigate stress up to $40 \%$ depletion of field capacity . These results are in parallel with those published by Nakoda et al. (2000) and Ben - Ghedalia et al.(2001). Also , these studied character followed the same previous trend and their values were significantly declined and gradually with planting from the $20^{\text {th }}$ April up to the $20^{\text {th }}$ June , in both growing seasons. Andhale et al.(2007) explained this relationship and stated that days required to $50 \%$ flowering and physiological maturity of pearl millet were also remarkably influenced under varying sowing time. Late sown crop advanced the flowering and maturity over early sowing.Increasing nitrogen fertilizer level from 80 up to $100 \mathrm{~kg} \mathrm{~N} /$ fad. increased fresh and dry forage yield by $13.64 \%$ and $13.58 \%$, they reached $23.69 \%$ and $27.67 \%$ as the application of $120 \mathrm{~kg} \mathrm{~N} / \mathrm{fad}$., respectively, in the second season. It was noticed that , fresh and dry forage yield were also significantly affected by $(I R \times S D)$ and $(\mathrm{SD} \times \mathrm{N})$ interactions. In both growing seasons, sowing the seeds on the $20^{\text {th }}$ April under the circumstances of $40 \%$ depletion of field capacity awarded the highest averages 32.18 and 33.44 ton/fad. for fresh forage yield and 19.31 and 20.00 ton/fad. for dry forage one. They were followed by 26.45 and 30.57 ton/fad. for the first trait and 15.87 as well as 18.35 ton/fad. for the second one as sowing the seeds on the same date under the condition of $60 \%$ depletion of field capacity .Eventually, the second order interaction ( IR $\times \mathrm{SD} \times \mathrm{N}$ ) had no significant effect on fresh and dry forage yield of pearl millet.
Water use efficiency for pearl millet plants was significantly affected by irrigation regimes through the two growing seasons, the highest means $(6.54$ and $5.90 \mathrm{~kg}$ $/ \mathrm{m}^{3}$ ) attributed to $80 \%$ depletion of field capacity, whereas the lowest ones (5.40 and $\left.5.18 \mathrm{~kg} / \mathrm{m}^{3}\right)$ associated with $40 \%$ depletion of field capacity . Orians and Solbrig (1977) explained the relation between the amount of yield and water stress, they stated that the close association between loose of water and entrance of $\mathrm{co}_{2}$ through stomata and the morphological and physiological traits affecting these gas exchanges prevent plants capable of high rates of photosynthetic in moist soil from being able to maintain high rates in dry soil. Beside that Bunce (1981), reported that plants with the highest rates of photosynthesis in most soil were least able to maintain high rates photosynthesis or to grow well in dry soil. The differences among plants at high leaf water potentials were caused by differences in my- sophyll conductance.

Significant gain also had been achieved for the effect of different rates of nitrogen fertilizer on WUE which was markedly increased with enhancing that rate from 80 up to $120 \mathrm{~kg} \mathrm{~N} / \mathrm{fad}$. in both growing seasons. These results may be due to nitrogen fertilizer is considered as a main source of protein and nucleoprotein in the plants, in such combinations proteins serve as catalysts and as directors of metabolism, as well as nitrogen is an integral part of the chlorophyll molecule, an adequate supply of nitrogen is associated with vigorous vegetative growth and a deep green color. For these above reasons, nitrogen fertilizer plays an important role for enhancing plant dry matter that had positive effect on crop yield, as explicated by Tisdalel and Nelson (1966). 
relationship between water use efficiency and the water lost by transpiration or the combined losses from evaporation and transpiration(ET) that were markedly affected by the change of day and night temperature .
Use of ET results in more variability in WUE because E is affected by leaf cover and frequency of soil wetting, independently of temperature (Tanner,1981).

Table:(8) Effect of irrigation regimes, sowing dates and nitrogen fertilizer rates on water use efficiency $\mathrm{kg} /$ $\mathrm{m}^{3}$ of pearl millet in 2013 and 2015 seasons

\begin{tabular}{|c|c|c|c|c|c|c|c|c|c|}
\hline \multirow[t]{2}{*}{$\begin{array}{l}\text { Irrigation } \\
\text { regime } \\
\text { (IR) }\end{array}$} & \multirow[t]{2}{*}{$\begin{array}{c}\text { Sowing } \\
\text { date(SD) }\end{array}$} & \multicolumn{3}{|c|}{$\begin{array}{l}2013 \text { season } \\
\text { Nitrogen fertilizer rate } \\
\text { (N) } \mathrm{kg} \text { N/fad. }\end{array}$} & Mean & \multicolumn{3}{|c|}{$\begin{array}{l}2015 \text { season } \\
\text { Nitrogen fertilizer rate } \\
\text { (N) } \mathrm{kg} \text { N/fad. }\end{array}$} & \multirow[t]{2}{*}{ Mean } \\
\hline & & 80 & 100 & 120 & & 80 & 100 & 120 & \\
\hline $40 \%$ & $20^{\text {th }}$ April & 6.32 & 7.18 & 7.94 & 7.15 & 6.45 & 7.05 & 7.78 & 7.09 \\
\hline \multirow[t]{4}{*}{$\left(\mathrm{IR}_{1}\right)$} & $20^{\text {th }}$ May & 5.03 & 5.68 & 6.55 & 5.75 & 5.25 & 5.89 & 6.15 & 5.76 \\
\hline & $20^{\text {th }}$ June & 3.01 & 3.24 & 3.65 & 3.30 & 2.41 & 2.72 & 2.90 & 2.68 \\
\hline & Mean & 4.79 & 5.36 & 6.04 & 5.40 & 4.70 & 5.22 & 5.61 & 5.18 \\
\hline & $20^{\text {th }}$ April & 6.01 & 6.88 & 7.44 & 6.78 & 7.26 & 8.21 & 8.98 & 8.15 \\
\hline $60 \%$ & $20^{\text {th }}$ May & 5.34 & 6.06 & 7.22 & 6.21 & 6.17 & 6.72 & 7.38 & 6.76 \\
\hline \multirow[t]{3}{*}{$\left(\mathrm{IR}_{2}\right)$} & $20^{\text {th }}$ June & 3.54 & 3.93 & 4.57 & 4.01 & 2.19 & 2.49 & 2.71 & 2.46 \\
\hline & Mean & 4.96 & 5.62 & 6.41 & 5.66 & 5.21 & 5.81 & 6.36 & 5.79 \\
\hline & $20^{\text {th }}$ April & 7.67 & 8.11 & 9.26 & 8.35 & 6.69 & 8.35 & 9.27 & 8.10 \\
\hline $80 \%$ & $20^{\text {th }}$ May & 5.25 & 7.11 & 8.20 & 6.85 & 6.73 & 7.51 & 8.28 & 7.51 \\
\hline \multirow[t]{2}{*}{$\left(\mathrm{IR}_{3}\right)$} & $20^{\text {th }}$ June & 3.41 & 4.55 & 5.31 & 4.42 & 1.82 & 2.15 & 2.34 & 2.10 \\
\hline & Mean & 5.44 & 6.59 & 7.59 & 6.54 & 5.08 & 6.00 & 6.63 & 5.90 \\
\hline Mean of & $20^{\text {th }}$ April & 6.67 & 7.39 & 8.21 & 7.42 & 6.80 & 7.87 & 8.68 & 7.78 \\
\hline Sowing & $20^{\text {th }}$ May & 5.21 & 6.28 & 7.32 & 6.27 & 6.05 & 6.71 & 7.27 & 6.67 \\
\hline dates(SD) & $20^{\text {th }}$ June & 3.32 & 3.91 & 4.51 & 3.91 & 2.14 & 2.45 & 2.65 & 2.41 \\
\hline \multicolumn{2}{|c|}{$\begin{array}{l}\text { Mean of } \\
\text { Nitrogen rates }(\mathrm{N})\end{array}$} & 5.06 & 5.86 & 6.68 & & 4.99 & 5.68 & 6.20 & \\
\hline \multicolumn{10}{|c|}{ LSD at $0.05 \%$ level for } \\
\hline \multicolumn{2}{|c|}{ Irrigation regimes (IR) } & \multicolumn{4}{|c|}{0.25} & \multicolumn{4}{|c|}{0.21} \\
\hline \multicolumn{2}{|c|}{ Sowing dates(SD) } & \multicolumn{4}{|c|}{0.21} & \multicolumn{4}{|c|}{0.22} \\
\hline \multicolumn{2}{|c|}{ Nitrogen rates $(\mathrm{N})$} & \multicolumn{4}{|c|}{0.16} & \multicolumn{4}{|c|}{0.09} \\
\hline \multicolumn{2}{|c|}{ IRxSD } & \multicolumn{4}{|c|}{0.37} & \multicolumn{4}{|c|}{0.37} \\
\hline \multicolumn{2}{|l|}{ IRxN } & \multicolumn{4}{|c|}{0.28} & \multicolumn{4}{|c|}{0.17} \\
\hline \multicolumn{2}{|l|}{ SDxN } & \multicolumn{4}{|c|}{0.28} & \multicolumn{4}{|c|}{0.17} \\
\hline \multicolumn{2}{|l|}{ IRx SDx N } & \multicolumn{3}{|c|}{0.49} & & \multicolumn{3}{|c|}{0.29} & \\
\hline
\end{tabular}

All the studied interactions had significant influence on that trait, in both growing seasons. For example, sowing pearl millet plants on the $20^{\text {th }}$ April under the condition of $80 \%$ depletion of field capacity awarded the highest averages of WUE ( 8.35 and 8.10 $\left.\mathrm{kg} / \mathrm{m}^{3}\right)$, whereas the lowest anes $\left(4.01\right.$ and $2.46 \mathrm{~kg} / \mathrm{m}^{3}$ ) were obtained from sowing the plants on the $20^{\mathrm{th}}$ June under the circumstances of $60 \%$ depletion of field capacity. On the same line, that studied property was affected significantly by the second order interaction $(\mathrm{IR} \times \mathrm{SD} \times \mathrm{N})$. The highest efficiency of water use , 9.26 and $9.27 \mathrm{~kg} / \mathrm{m}^{3}$ were recorded as sowing the plants on the $20^{\text {th }}$ April with the rate of $120 \mathrm{~kg} \mathrm{~N} / \mathrm{fad}$. under the irrigation of $80 \%$ depletion of field capacity, on the contrary the lowest means $\left(3.01\right.$ and $\left.2.41 \mathrm{~kg} / \mathrm{m}^{3}\right)$ were gained as planting the seeds on the $20^{\text {th }}$ June with the application of $80 \mathrm{~kg} \mathrm{~N} / \mathrm{fad}$. under the irrigation of $40 \%$ depletion of field capacity, in both growing seasons.

\section{REFERENSES}

Abdel-Gawad, K. I. (1993 ). Evaluation of cowpea varieties for intercropping with sorghum and corn. Bull. Fac. Agric., Cairo Univ.,( 44):571-586.

Aftab W.; A. Hussain ; A. Ahmad; M. Rafiq; A. R. Goheer and M. Ibrahim (2004). Effect of sowing date and plant density on growth, light interception and yield of wheat under semi arid conditions. Inter. J.Agric.,6: 1119-1123.
Andhale R. P.;S. H. Shinde; B.T. Sinare. and A.D. Tambe (2007).Effect of sowing dates and fertilizer levels on phenology and heat unit accumulation in pearl millet (Pennisetum glaucum L.)hybrids. J. Maharashtra Agric. Univ., 32(3): 401-402.

Ben-Ghedalia, D.; R. Solomon; J. Miron; E. Yosefm; Z. Zomberg; E. Zukerman; A. Greenberg and T. Kipnis ( 2001). Effect of water salinity on the composition and in vitro digestibility of winter annual rye grass grown in the Arava desert Anim. Feed Sci. Techn.,91: 139-147.

Bunce,J.A.(1981). Relationships between maximum photosynthetic rates and photosynthetic tolerance of low leaf water potentials. Can. J. Bot. 59, 769-774.

Dakheel ,A.J., G. Shabbir and A.Q . Al-Gailani (2009). Yield stability of pearl millet genotypes under irrigation with different salinity levels. Europ. J. Sci. Res., 37: 288-301.

Deshmukh, S. P. ; J. G. Patel and A. M. Patel (2013). Ensuing economic gains from summer pearl millet (pennisetum glaucum L.)due to different dates of sowing and land configuration. African J. Agric., 8(49):6309-6415.

Eck ,H.V. (1988). Winter wheat response to nitrogen and irrigation. Agron. J., 80 (6) : 902 -908 .

Hussain, A.; M. Rashid and M. Yassin (1987). Advantages of FYM and its better use. Zarate Nama Lahore, $33: 17-18$. 
Ibrahim, Y. M. (1985). Agronomic and physiological characters of pearl millet(Pennisetum americanum L.K.Schum) grown under sprinkle irrigation gradient. Desertation Abst.Inter., B.46

Kramer , P. J.(1983). Water relations of plants, pp. 360362 .Wiley, New York.

Kwapata, M. B. and A. E. Hall (1990). Response of contrasting vegetable - cowpea cultivars to plant density and harvesting of young pods. I. Production . ( C.F. Field Crops Res. 24: 1-10)

Maiti, R. and H.G. Rodriguez (2010). Pearl millet: potential alternative for grain and forage for livestock in semiarid regions of mexico. IJBSM 1(1):45-47.

Nakoda, B.; A. Hashemi-Desfouli and N. Banisadr (2000). Water stress effects on forage yield and quality of pearl millet. Iranin J. Agric. Sci., 31(4): 701-712.

Newman, Y., E.D. Jennings, J. Vendramini and A. Blount (2010). Pearl millet (pennisetum glaucum): Overview and management. SS-AGR-337, one of a series of the Agronomy Department, Florida Cooperative Extension Service, Inst. Food and Agri. Sci., Univ. Florida. Original publication date September 2010. Visit 2518 Afr. J. Agric. Res. the EDIS website at http://edis.ifas.ufl.edu.

Okpara, D.A. and C. P. E. Omaliko (1995). Forage millet response to irrigation and nitrogen fertilization in the Derived Savanna Zone of Nigeria. Ghana. J. Agric. Sci., 28-29, 37-43.
Orians,G.H. and O. T. Solbring (1977). A cost-income model of leaves and roots with special reference to arid and semi- arid areas. Am. Nat. 111, 677-690.

Snedecor , G. W. and W. G. Cochran(1981). Statistical Methods. Seventh Edition. Iowa State Univ. Press, Ames, Iowa, USA.

Tanner, C.B. (1981). Transpiration efficiency of potato. Agron. J. 73, 59-64.

Tariq, M. ; M. Ayub; M. Elahi; A. H. Ahmad ; M. N. Chaudhary and M. A. Nadeem (2009). Forage yield and some quality attributes of millet (Pennisetum americannum L.) hybrid under various regimes of nitrogen fertilization and harvesting dates. African J. Agric., 6(16), pp. 3883-3890.

Tazaki,T.; K. Ishihara and T. Usijima (1980). Influence of water stress on the photosynthesis and productivity of plants in humid areas. In "Adaptation of plants to water and High Temperature Stress"( Turner N.C. and P. J. Kramer, eds.) pp. 321-330 . Wiley ,New York.

Tisdale, S.L. and W.L. Nelson (1966). Soil Fertility and Fertilizers, Second edition Book, The Macmillan Company, New York.

Yassin ,M. I. ; Idris,A.E. and Marhoum,M.A.(2014). Effect of nitrogen fertilizer on irrigated forage pearl millet (Pennisetum americanum L.K. Shcum). Universal J. Agric. Res., 2(2): 56-60

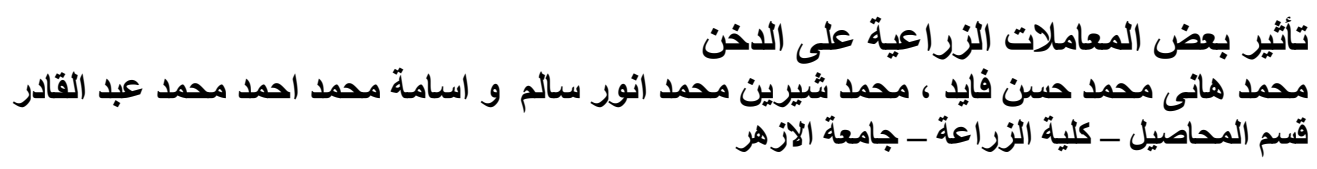

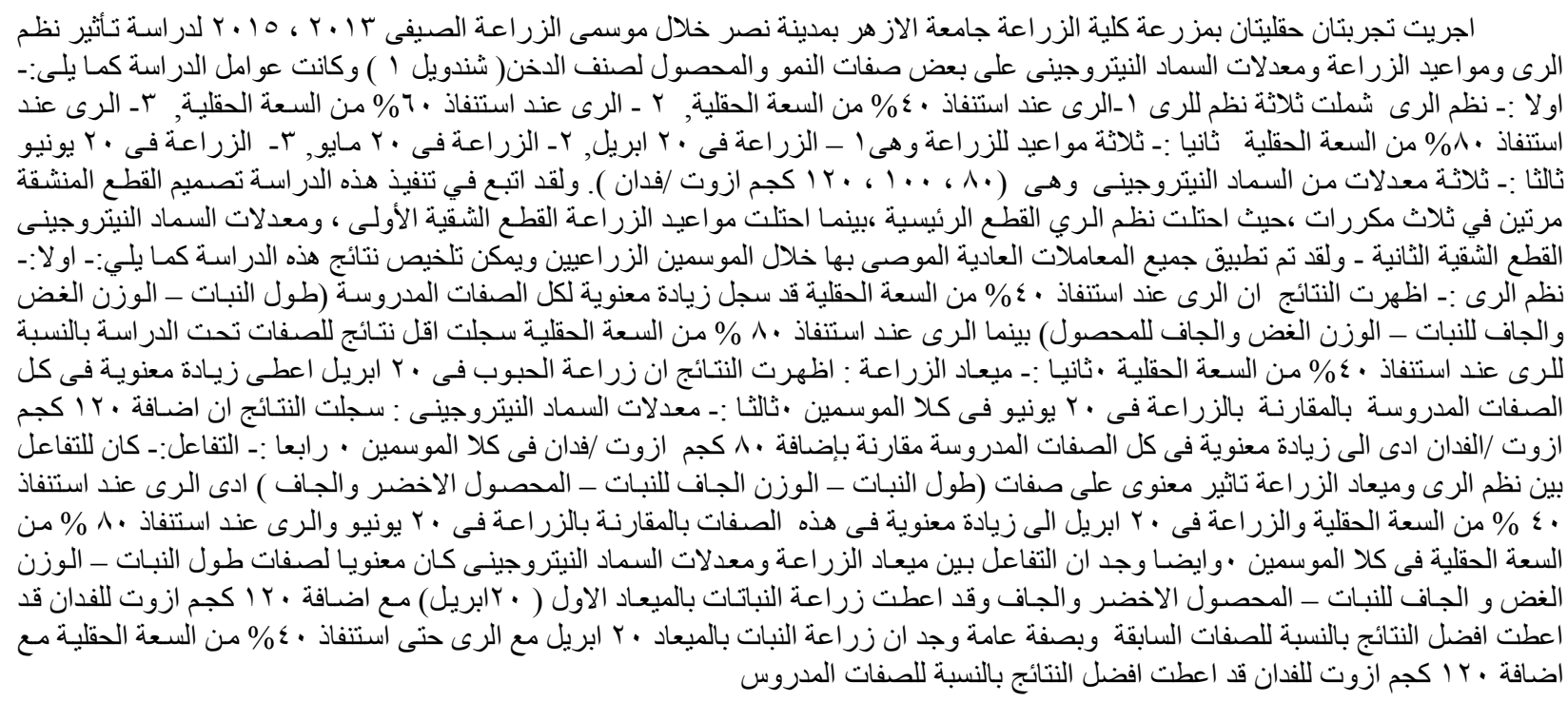

